Jap. J. Psychol.,

1968, Vol. 39, No. 5, 248-257.

\title{
楕円近似による白色感域
}

\author{
日立製作所 中央研究所 \\ 本城和夫
}

光源色の白色感域については, カラーテレビの色彩, 照 明の演色性なぞの基本的な問題であるにもかかわらずこ れまであまり研究されていない上うである. 数少ない報 告のなかで,たと党ば Kelly の色名汇関する研究(1943) が一般に高く評価されているが，これ和いても白色の 領域が明らかにされているわけではない。 むしろ, 白色 感域関するものとしては, Hurvich \& Jameson の研 究 (1951) が挙げられる。彼らは, 刺激視野和よび順応 視野の色温度特よび輝度がそれぞれ独立に可変でき，ま た，刺激視野の大きさと露出時間が可変できる装置をつ くり, 黒体軌跡に近似した刺激光を呈示して白色感の有 無を調べた。 そして, 刺激視野の小さい場合には, $5000^{\circ} \mathrm{K}$ 〜 7000 $\mathrm{K}$ の色温度を境にして白色を感じる刺激光に はより高い輝度が要求されるが, 刺激視野を大きくする ことによって輝度をあげることなく白色の領域の生じる ことを明らかにした。また，順応視野に順応した場合， それと同じ色温度の刺激光に対しては比較的低い輝度で も白色に感じることを報告している。, 一方, Helson \& Michels (1948) も色順応の効果を白色の移動としてと ら光, 順応光の色度方向に白色感が移動することを示し た。

このような研究がある一面, 白色といら言葉は特に光 源色飞物いて漠然として挌り，たと光げけい光ランプの 色度区分 (JIS，1967）飞定められている範囲の白色は， 実際に白色と感じる領域を必ずしも意味するのではな く, ぞちらかと言兄ば, 単なる呼称, あるいは記号とし て理解すべきだと思かれる。このように白色感域が明確 化されず, 使用される言葉が瞹昧である一因は, 色感覚 が単飞放射エネルギーだけではなく, 刺激の大ささ, 布 置条件の変化伴なら神経機能の状態, 西るいは, 判断 基準の個人差に左右されるためと考光られる。

ところで, 刺激汶対する反応が正規分布で, かつ, 刺 激連続体と反応連続体が直線的な関係汇あると仮定する と, 確率 $P$ で反応する色刺激を $x, y$ 色度図上飞求める ことが可能でめる. 本研究に怙いては, 確率 $P$ を 0.5 と した白色点を求め，これによって囲まれる白色の範囲を 求める実験を行なった.

\section{実験 装置}

実験装置をFig. 1 亿示すよう亿，刺激光をつくる混 色部と観測条件をつくる視野部から構成し暗室に配置し た.

混色部, 光源 $\mathrm{L}_{1}, \mathrm{~L}_{2}, \mathrm{~L}_{3}$ は指定電圧で色温度 $2854^{\circ} \mathrm{K}$ に校正されたガス入りタングステン電球で，それぞれべ

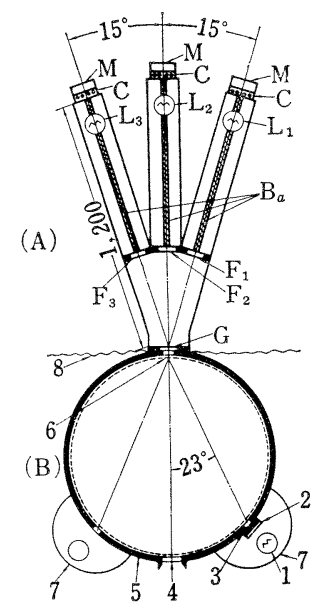

(A) 混色 部

$\mathrm{L}_{1}, \mathrm{~L}_{2}, \mathrm{~L}_{3}$ : 光度標準電球 $(100 \mathrm{~V}, 100 \mathrm{~W})$

$\mathrm{F}_{1}:$ 赤色フィルタ

$\mathrm{F}_{2}$ : 青色フィルタ

$\mathrm{F}_{3}:$ 緑色フィル夕

$\mathrm{G}$ ：きせガラス

$\mathrm{B}_{a}:$ ベンチパー

$\mathrm{C}$ : 計 数 器

$\mathrm{M}:$ E一夕-

(B) 視 野 部

$1:$ 光度標準電球 $(100 \mathrm{~V}, 100 \mathrm{~W})$

$2:$ ニュートラルフィルタ

3:オパールガラス（マットしたるの）

$4:$ 観 測 空

$5:$ 積 分 球

$6:$ 刺激光呈示空

7 : 光 源 箱

8 : 暗

FIG. 1. 実験装置 
ソチバー $\mathrm{B}_{a}$ に組达んだ電球架台に取付けてある．この 電球にそれぞれ赤, 緑, 青の色ガラスフィルタ $\mathrm{F}_{1}, \mathrm{~F}_{3}, \mathrm{~F}_{2}$ を組合せて，3 種類の色光で視野中心の空にとりつけた 拡散面 $\mathrm{G}$ 照射し，その透過光を刺激光とする．刺激光 の輝度执よび色度は両面マットしたさせガラスの拡散面 そ光源の距離をモータ Mの駆動によって変光て調整する が，この調整は観測者側でも実験者側でも手元の操作ス イッチで任意に行なうことができる．な拉，光源の位置

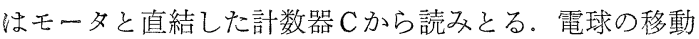
速度は $5 \mathrm{~cm} / \mathrm{sec}$ で, これは $x, y$ 色度図上の白色近傍 で毎秒大体 0.01 の長さに相当する。また，電球の可動 範囲は拡散面を基点として，大体 450 1000 mm であ る.この $450 \mathrm{~mm}$ という值を定めたのは，これ以上短 くした場合，構造上の制約もあるが色导らの原因あるい は光源距離の設定誤差による刺激光の輝度変化が大きく なって，再現性がそしくなるためである。一方，刺激光 呈示面（拡散面）G対する入射角以混色をよくする意 味からできるだけ小さい方がよいわけであるが，本装監 の場合 2 つ色光については入射角 15 度とした。拡散 面 Gは完全拡散面であることが望ましいが，本装置の拡 散面について入射角 $\pm 15^{\circ}$ とて余弦法則からのはずれ を調べた結果，約 1\%であった。したがって，実験には 支障をさたさない程度の拡散性を有すると考兄られる。

視野部 比較的均一な色度と輝度を有する視野を得る ために，内径 $1 \mathrm{~m}$ の積分球を製作し，内面を $\mathrm{BaSO}_{4}$ を 顔料とする光束計塗料で吹付塗装した. Fig. 1 に示すよ 5 に積分球 5 の観測空 $4(5 \times 10 \mathrm{~cm})$ にはゴム製の視野 マスクを取付けて観測者の目を固定させると同時に迷光 が入るのを防いだ。この観測空の対称の位置には視角 $2^{\circ}$ になるように值径 $3.5 \mathrm{~cm}$ の刺激光呈示用の小空 6 を開 けて，この小空から混色部の刺激光をみるように積分球 を配置した。 また，順応する色光を呈示するための光源 は, 光源箱 7 の中に組込及, 色ガラスフィルタ 2 , 拡散 透過面 3 を組合せて直径 $4.8 \mathrm{~cm}$ の空を通して球内面を 照射した。

\section{器械原刺激の測定}

光源である電球と色フィルタとの各組合せによる拡散 面の透過光を各器械原刺激とすれば, 各器械原刺激の色

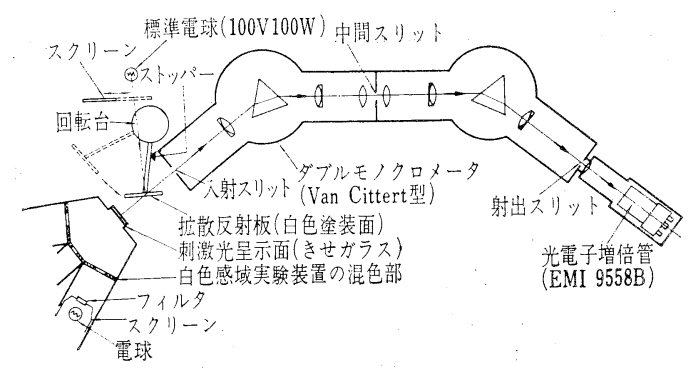

FIG. 2. 器械原刺激の分光分布測定
TABLE 1

器械刺激の色度座標と輝度範囲

\begin{tabular}{|c|c|c|c|}
\hline \multirow{2}{*}{$\begin{array}{ll}\text { 器 } & \text { 械 } \\
\text { 刺 激 } \\
\end{array}$} & 色 度 & 巫＼cjkstart標 & \multirow{2}{*}{ 輝 $(\mathrm{abs})^{\text {度 }}$} \\
\hline & $x$ & $y$ & \\
\hline 赤 & 0.7321 & 0.2679 & $5.3_{3}-0.7_{5}$ \\
\hline 緑 & 0.2976 & 0.6599 & $36.0_{8}-5.3_{8}$ \\
\hline 青 & 0.1871 & 0.1181 & $11.3_{7}-1.7_{1}$ \\
\hline
\end{tabular}

度は, 原理的には各構成部品, すなわら電球の分光分 布, 色ガラスフィルタおよびきせガラスの分光特性から 算出できる。しかし，現段階ではきせガラスの分光特性 を手軽に正確に測定することは難しい。また，光源位置 を変えた輝度の相対值についても原理的には光源からの 距離の逆自乗に比例するが, 距離が短い場合には受光面 おっよび光源の大きさ，ならびに迷光などの影響でこの逆 自乗則が成立しなくなる。一方, 刺激光の色度は器械原 刺激の色度扣よび相対的な輝度比に依存するから，これ らの測定確度が重要である. そこで, 実際の使用状態に 扣いて, 器械原刺激の分光分布を分光測光器によって測 定した。 また, 輝度については光電管特よびマクベス照 度計を用いて校正した。

分光分布の測定 実際の実験状態では 3 つの電球をそ れぞれ単独に点灯することはないので， 3 つの電球の点 灯電圧を 1 個の電圧計 (0.2 級) で和さえた. そして, しゃ光板を用いて 2 つの電球光をしゃへいし, 器械原刺 激各個について測定した。な拉, 色温度 $2854{ }^{\circ} \mathrm{K}$ で点灯 する3つの電球の点灯電圧はそれぞれ不揃いであるが, 各電球のリード線の抵抗を加減して各電球の指定電圧が それぞれ印加されるようにした. 分光分布の測定は Fig. 2 に示すよ5に, 色温度 $2854^{\circ} \mathrm{K}$ の光度標準電球で照射 した拡散反射板（硫酸バリウム白色塗装面）を標準とし て置換法で測定した。すなわち，スクリーン和よび回転 台にとりつけた拡散反射板を図の点線の位置に抮いて器 械原刺激の光をダブルモノクロメータに入れる. また， スクリーン，拡散反射板を実線の位置に呿いて標準電球 の光をダブルモノクロメータに入れる. この場合, 拡散 板物よび器械原刺激の発光面はダブルモノクロメータの コリメータレンズに対して full-aperture になるように 配置した。本実験の場合，スリット幅一定で測定したが 波長 450，550，650 nm 飞拉いて波長幅はそれぞれ 3.9， $8.3,14.4 \mathrm{~nm}$ である。ところで, 今, 器械原刺激拈よ び標準電球の分光放射強度 $P_{i}(\lambda)$ 物よび $P_{S}(\lambda)$ に対し て光電子増倍管の出力をそれぞれ $I_{\imath}(\lambda), I(\lambda)$ とすれば 器械原刺激の分光放射強度は次の式から得られる。

$$
P_{i}(\lambda)=k \cdot \rho(\lambda) \cdot P_{s}(\lambda) \cdot I_{i}(\lambda) / I(\lambda)
$$

ここに,

$k$ : 標準電球, 刺激光呈示面, モノクロメータの入射 
スリットなどの相互位置関係で決まる比例常数. $\rho(\lambda)$ : 反射板の分光反射率

$P_{s}(\lambda)$ : 反射板に入射する標準電球の分光放射強度で,

本実験の場合, $2854^{\circ} \mathrm{K}$ の扊色体と仮定して求め た。

な拈，実際の測定に際しては各出力 $I(\lambda), I_{i}(\lambda)$ を交 互に 2 度ずつ测定し, それぞれ $0.3 \%$ 以下の再現性を確 めてから平均值で処理した. 以上のような測定法により 求めた器械原刺激赤, 緑, 青の分光分布からそれぞれの 色度座標 $x, y$ を計算すると Table 1 に示す値が得られ た。

輝度の測定 本実験の場合, 各器械原刺激の間の輝度 の相対值,ならびにそれぞれの器械原刺激に括いて種々 の電球位置に対する輝度変化の相対值が刺激光の色度を 求める上に重要である. このうち前者の関係は分光分布 の値から算出した刺激值の $Y$ の值を用い, また, 後者の 関係は直線性を確かめた光電管を用いて求めた。すなわ ち, 後者の場合, 入射光束の変化 $2: 1 \sim 10: 1$ に対して $0.2 \%$ 以内の䛊差で成立する直線性のよい光電管を刺激 光是示面に取付けて計数器の目盛 40 きざみ, すなわち 電球距離 $2 \mathrm{~cm}$ 間隔で輝度変化の相対值を求めた. な お, 計数器の読みで 1 目盛間隔に対しては Lagrange の 3 次補間で求めた。 また, 輝度の絶対值については本実 験の場合異色測光となり, 簡易な物理測光よりは視感測 光の方が信頼度が高いと考方られるのでマクベス照度計 を輝度計に校正して測定した. 結果をTable1に示す.

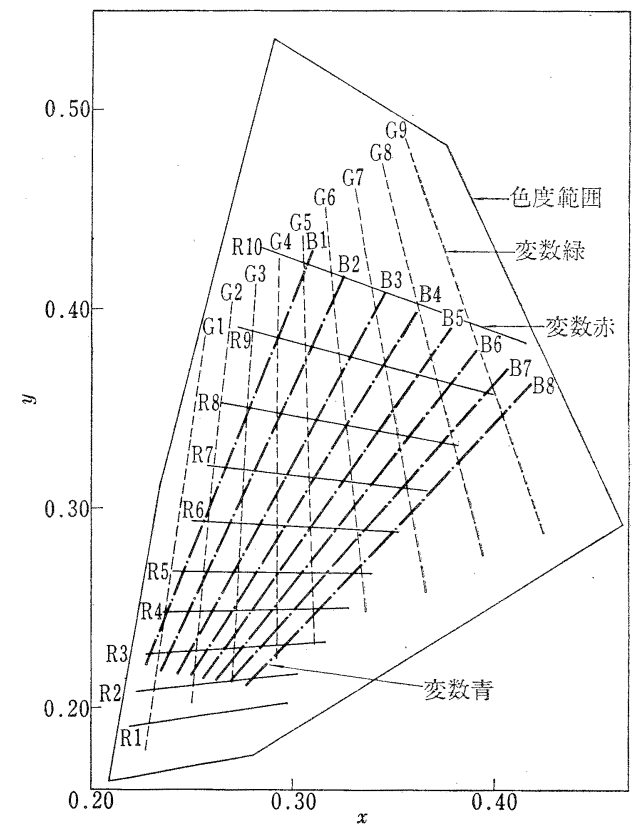

FIG. 3. 刺激光の色度範囲と軌跡

\section{刺激光の色度範囲および誤差の検討}

色度範囲 $x_{1}, y_{1} ; x_{2}, y_{2} ; x_{3}, y_{3}$ を各器械原刺激の色度 座標とすると, 混色して得られる色光の色度座標 $x_{0}, y_{0}$ は次の式で得られる。

$$
\begin{aligned}
& x_{0}=\frac{S_{1} x_{1}+S_{2} x_{2}+S_{3} x_{3}}{S_{1}+S_{2}+S_{3}} \\
& y_{0}=\frac{S_{1} y_{1}+S_{2} y_{2}+S_{3} y_{3}}{S_{1}+S_{2}+S_{3}}
\end{aligned}
$$

ここに

$S_{1}, S_{2}, S_{3}$ : 各器械原刺激の刺激和, $S_{i}=X_{i}+Y_{i}+Z_{i}$

$$
\text { または， } \quad S_{i}=\frac{Y_{i}}{y_{i}} \quad(i=1,2,3)
$$

今, 2 つの器械原刺激, たと放ば赤と緑の輝度を一定 にして残りの器械原刺激青の輝度を変化させるときの刺 激光の色度図上の軌跡は, 上の式から次式のように求ま り直線となる。

$$
\begin{aligned}
y_{0}= & \frac{\left(S_{1} y_{1}+S_{2} y_{2}\right)-\left(S_{1}+S_{2}\right) y_{3}}{\left(S_{1} x_{1}+S_{2} x_{2}\right)-\left(S_{1}+S_{2}\right) x_{3}} x_{0} \\
& +\frac{\left(S_{1} x_{1}+S_{2} x_{2}\right) y_{3}-\left(S_{1} y_{1}+S_{2} y_{2}\right) x_{3}}{\left(S_{1} x_{1}+S_{2} x_{2}\right)-\left(S_{1}+S_{2}\right) x_{3}}
\end{aligned}
$$

ところで, 器械原刺激の各輝度が零でない有限の最小 值之最大值を有する場合の刺激光の色度は, 各器械原刺 激の色度座標を結ぶ三角形より小さい六角形の周上とそ の内部に存在する。すなわち, 六角形の頂点は器械原刺 激の刺激和の最大と最小の組合せによって決なる。本実 験の場合, 器械原刺激の色度と輝度範团は Table 1 亿示 す通りであるから Fig. 3 に示す刺激光の色度範囲とな る。

誤差の検討 器械原刺激の分光分布および輝度の相対 值の測定に特いて，その測定値の誤差は 1 3\% と考え られるので刺激光の色度に持よぼす影響がどの程度かを 検討した。式 (2)を全微分することにより刺激光の色度 変化 $\Delta x, \Delta y$ は,

$$
\Delta x_{0} \leqq\left|\frac{\partial x_{0}}{\partial S_{1}}\right|\left|\Delta S_{1}\right|+\left|\frac{\partial x_{0}}{\partial S_{2}}\right|\left|\Delta S_{2}\right|+\left|\frac{\partial x_{0}}{\partial S_{3}}\right|\left|\Delta S_{3}\right|
$$

同様に，

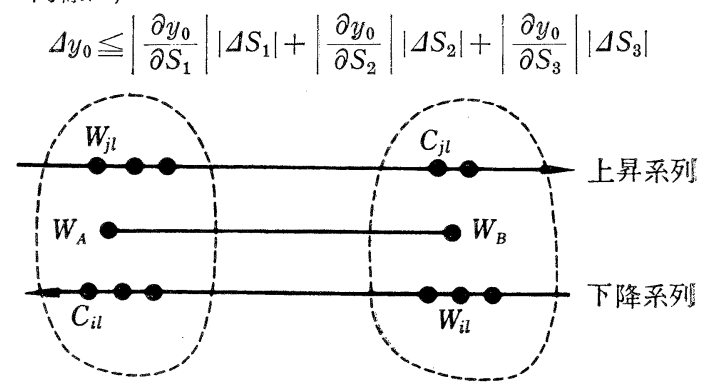

$W_{A}, W_{B}$ : 白色点

W..,C.. : 白色反応打よび色味反応 $j, i:$ 上昇系列拉よび下降系列

FIG.4. 白色点の求め方 
である。

ここに,

$$
\begin{aligned}
& \frac{\partial x_{0}}{\partial S_{1}}=\frac{S_{2}\left(x_{1}-x_{2}\right)+S_{3}\left(x_{1}-x_{3}\right)}{\left(S_{1}+S_{2}+S_{3}\right)^{2}} \\
& \frac{\partial x_{0}}{\partial S_{2}}=\frac{S_{1}\left(x_{2}-x_{1}\right)+S_{3}\left(x_{2}-x_{3}\right)}{\left(S_{1}+S_{2}+S_{3}\right)^{2}} \\
& \frac{\partial x_{0}}{\partial S_{3}}=\frac{S_{1}\left(x_{3}-x_{1}\right)+S_{2}\left(x_{3}-x_{2}\right)}{\left(S_{1}+S_{2}+S_{3}\right)^{2}}
\end{aligned}
$$

今, 標準の光 $\mathrm{C}$ 近傍の色度について検討すると $\Delta x, \Delta y$ はそれぞれほぼ 0.002〜0.006 になる。したがって，実 験汇支障をきたさない程度の信頼度はあると考光られ る.

\section{実 験}

方法 本装置に特いて 2 つの器械原刺激を特定の輝度 比で固定し，残りの 1 つの輝度を観測者が変化させて白 色点を求める極限法の形式により実験を行なった。この 場合, 上述のよう飞刺激光色度軌跡は直線となるが，こ の軌跡を予め各変数の色別化約 10 本ずつ定め, 輝度が 高くなる方向を上昇系列，低くなる方向を下降系列と乙 て色味反応と白色反応を求めた。 たと壳ば，变数赤の場 合, 上昇系列飞招いて器械原刺激赤の輝度が低いとこ ろ，すなわち，青緑のところからスタートして徐々に輝 度を上げ，始めて白色に感じる点 (白色反応)，さらに 楎度を上げて始めて赤味を感じる点（色味反応）を求め た。逆に, 下降系列に蛙いて, 器械原刺激赤の輝度が高 いところ，すなわち，赤味の領域からスタートし，輝度 を低くして始めて白色に感じる点（白色反応）と始めて 青緑に感じる点を求めた。 そして，Fig. 4 亿示すように 互いに異なる系列の白色反応と色味反応， $W_{i l}, C_{\imath \imath}$ なら びに $W_{j l}, C_{j l}$ の各平均を白色点 $W_{A}, W_{B}$ とする.す なわら, 特定の軌跡上で白色点を $2 つ$ 求めるわけである

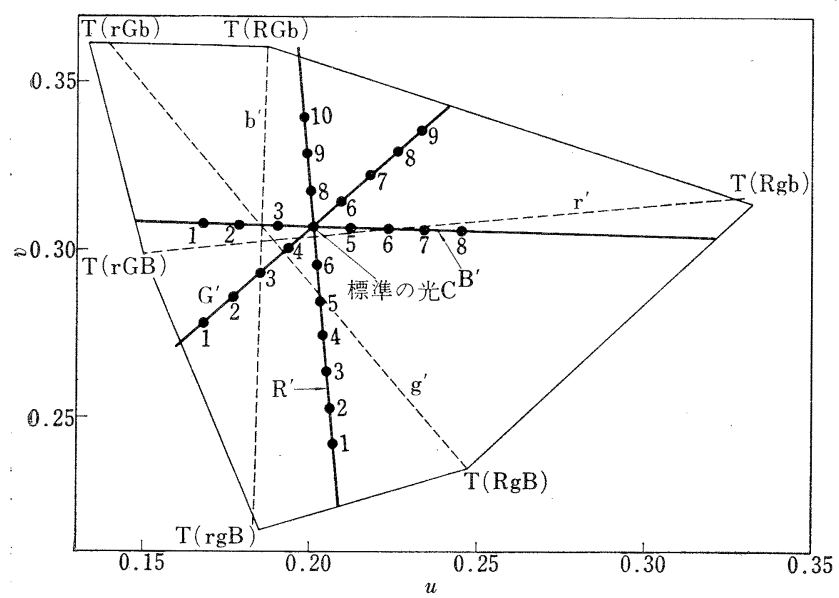

$R G B$ : 器械原刺激赤, 緑, 赤の最大刺激 $\mathrm{rgb}$ : 器械原刺激赤, 緑, 青の最小刺激

FIG. 5. 刺激光の $u v$ 色度図上の定点
が，次の式により $W_{A}, W_{B}$ が求められる.

$$
\begin{aligned}
& W_{A}=\frac{\sum_{l=1}^{n} W_{j l}+\sum_{l=1}^{n} C_{i l}}{2 n} \\
& W_{B}=\frac{\sum_{l=1}^{n} W_{i l}+\sum_{l=1}^{n} C_{j l}}{2 n}
\end{aligned}
$$

ここに, 添字は $j, i$ 上昇系列, 下降系列を意味する.

刺激光の軌跡 呈示する刺激光の軌跡であるが, 实験 の目的からいって軌跡の間隔はできるだけ等間隔である こと, 抢よび白色と判断される刺激光の輝度が同一であ ることが望むしい，そこで，Fig. 5 に示すように $u v$ 色 度図 ${ }^{1}$ 上（金子，1965；CIE，1963）で，標準の光 C の色 度座標を通る直線 $R^{\prime}, G^{\prime}, B^{\prime}$ 上飞执いて距離間隔約 0.11 の定点を求めた。な拈，この直線 $R^{\prime}, G^{\prime}, B^{\prime}$ 法それぞれ 各器械原刺激の色度座標之六角形の 1 つの頂点を結ぶ直 線に直交するものである.たと劣ば, 直線 $\mathrm{R}^{\prime}$ は赤の器 械原刺激の色度座標と六角形の 1 つの頂点 $\mathrm{T}(\mathrm{rGB})^{2}$ の 色度座標を結ぶ直線に直交する。ただし， $\mathrm{R}^{\prime}, \mathrm{G}^{\prime}, \mathrm{B}^{\prime}$ を このよ5な方法で定めたのは各直線のなす角度にできる だけ変化をもたせるためである。そして, 変数赤, 緑, 青の刺激光軌跡がそれぞれ $\mathrm{R}^{\prime}, \mathrm{G}^{\prime}, \mathrm{B}^{\prime}$ 直線上の定点を通 るように, 固定する 2 つの器械原刺激輝度比を定めた。 さらに, これらの定点の色度座標を有する刺激光の輝度 が約 20 abs になるように, 固定した $2 つ の$ 器械原刺激 の輝度の值を定めた．このようにして作った各变数の色 別の刺激光軌跡を $x y$ 色度図上に示すと Fig. 3 のよう になる。

観測者 観測者は男 3 名 [H (31 歳), S (22 歳), Y (21 歳)]でいずれも色彩実験の経験者である.

第 I 実験 人間が絶対判断で評価を行なう場合，その ときの心理, 生理条件に帰因して判断の基準が 不安定となり, その結果評価のバラッキが大き くなる. 実験者にとってこのようなバラッキは 不本意であるが，このようなことは日常生活に 括いて極く出たり末光の現象である。乙たがっ て, むしろ，一定時間内でのバラッキを調べて もあまり実際的でない。そこで, Fig. 3 亿示す 刺激光軌跡を毎実験時必ず 1 回だけ使用して行 なう実験を 25 回にわたって行なった。ただし， 刺激の呈示順序は変数の色別にランダムに行な った。な执，実験にあたって，電球の安定時間 11960 年 CIE-UCS 系座標と $x y$ 座標との 関係は次の通りである。

$$
u=\frac{4 x}{-2 x+12 y+3} \quad v=\frac{6 y}{-2 x+12 y+3}
$$

2 器械原刺激赤の最小刺激 $(\mathrm{r})$, 器械原刺激

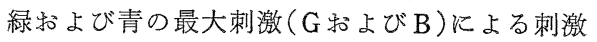
光. 
を考慮して観測実験を始める 10 分前に点灯し，その間 観測者は観測空化向って腰かけ目を閉じるか，または横 を向いて実験開始に備えた。

ところで，測色の分野では一般に $X Y Z$ 座標系が用い られてきたが，これを心理的にみた場合，スケールが感 覚的に不等間隔で必ずしも満足したものでない。したが って平均值とか標準偏差を求めても本来の数学的意味か らはずれる危険性を有する。このような意味から感覚的 飞等間隔を有する座標系が望をれていたが, 1963 年にい たり国際的に推奖された $u$ 座標系が出現した。 これは マンセル色票など物体色を中心に構成されたものである が，本実験のような光源色に叔いて子輝度が同じである との仮定にたって $u v$ 座標の使用が可能であると考光ら れる.すなわち, $u v 2$ 次元の座標で検討しても相対的な

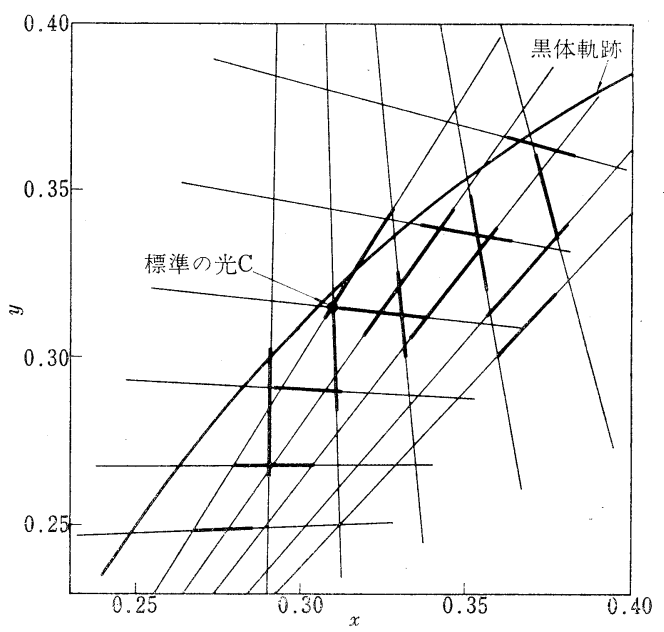

FIG. 6-(1) 観测者Yの白色感域（太線）

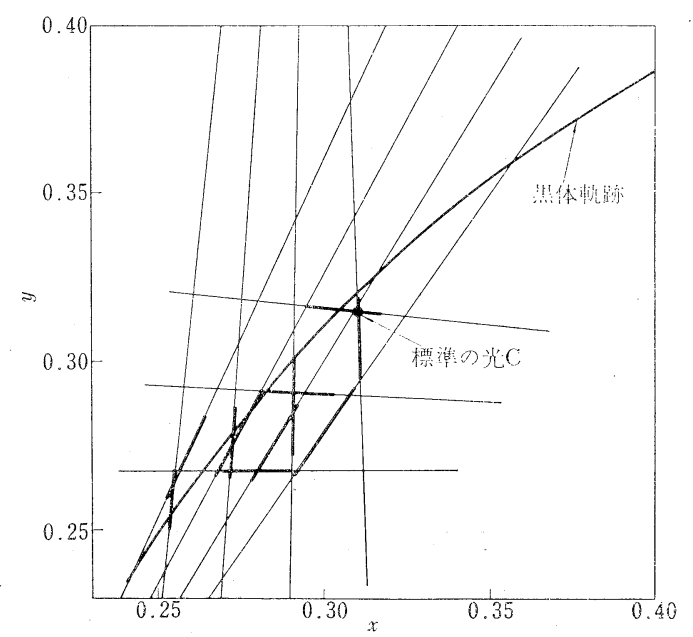

FIG. 6-(2) 観測者 S の白色感域（太線）
関倸は十分得られると考兄られる。そこで，得られた各 測定点の $x y$ 座標を $u v$ 座標に变換して式 $(5)$ か. 白色 点を求め, 65一度 $x y$ 座標汅変換しな拈した。観測者 別に白色点を求めこれを図示すると Fig. 6 の各太線の 両端になる。李わち、この太線の部分が白色と判断 される領域である。これらの図に执いて変数の色別で白 色感域が多少異なるが, いずれかの変数の色で少なくと も 1 度白色と判断すると考光られる範囲を観測者別倠 定すると，各観測者とも黒体軌跡を含み，その大きさは 大体同じである。しかし，告の位置は観測者 $\mathrm{Y}$ の場合幾 分異なり, 他の 2 名上り色温度の低い領域化白色が存在 する.一方, 観測者 $\mathrm{H}$ 呿よび $\mathrm{S}$ の場合は標準の光 Cより やや色温度の高い領域に白色が存在している。 また，

Fig. 6 から観測者を無視し, 誰れかが少なくとも 1 回以

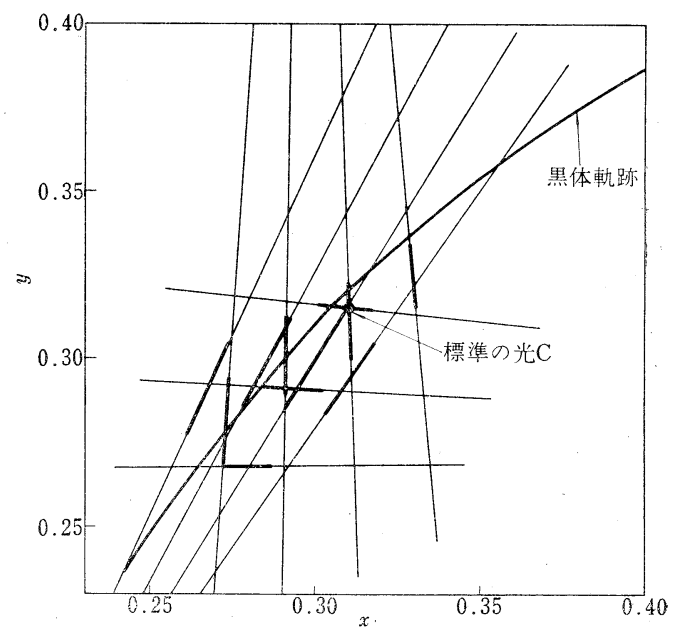

FIG. 6-(3) 観測者Hの白色感域（太線）

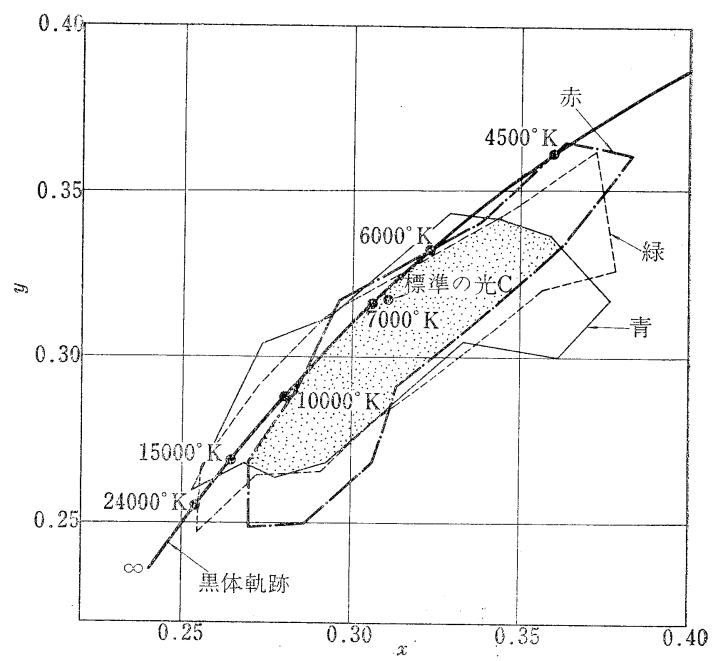

FIG. 7. 変数の色別による白色感域 
TABLE 2

標 準 偏 差

\begin{tabular}{|c|c|c|c|c|c|c|}
\hline \begin{tabular}{l|l} 
鼣測 \\
者
\end{tabular} & 刺 激 & $\begin{array}{c}\text { 下降系列 } \\
\text { 色味 点 }\end{array}$ & 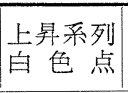 & $\begin{array}{l}\text { 下降系列 } \\
\text { 白色 点 }\end{array}$ & $\begin{array}{l}\text { 上昇系列 } \\
\text { 色昧 点 }\end{array}$ & $\begin{array}{l}\text { サソ } \\
\text { プル } \\
\text { 数 }\end{array}$ \\
\hline \multirow{6}{*}{ Y } & R 7 & 0.00991 & 0.01102 & 0.00991 & 0.01201 & 16 \\
\hline & $\mathrm{R} 8$ & 0.01650 & 0.01656 & 0.01683 & 0.00982 & 14 \\
\hline & G 6 & 0.00862 & 0.00842 & 0.01093 & 0.01473 & 16 \\
\hline & G 7 & 0.01072 & 0.01276 & 0.01460 & 0.01786 & 16 \\
\hline & B 5 & 0.02105 & 0.02152 & 0.02196 & 0.02108 & 17 \\
\hline & B 6 & 0.02035 & 0.02013 & 0.02756 & 0.01898 & 15 \\
\hline \multirow{5}{*}{$S$} & $\mathrm{R} 6$ & 0.00739 & 0.00885 & 0.00816 & 0.01278 & 20 \\
\hline & G 3 & 0.00678 & 0.00656 & 0.00811 & 0.00703 & 18 \\
\hline & G 4 & 0.00922 & 0.00894 & 0.00934 & 0.01003 & 24 \\
\hline & B 3 & 0.01173 & 0.01485 & 0.01413 & 0.01528 & 18 \\
\hline & B 4 & 0.01674 & 0.01640 & 0.01587 & 0.01588 & 13 \\
\hline \multirow{5}{*}{$\mathrm{H}$} & R 6 & 0.00769 & 0.00915 & 0.00925 & 0.00982 & 21 \\
\hline & G4 & 0.00730 & 0.00549 & 0.00785 & 0.00696 & 21 \\
\hline & G 5 & 0.00690 & 0.00840 & 0.00759 & 0.01149 & 13 \\
\hline & B 3 & 0.01581 & 0.01719 & 0.01790 & 0.01718 & 17 \\
\hline & B 4 & 0.01465 & 0.01383 & 0.01545 & 0.01697 & 14 \\
\hline
\end{tabular}

上白色と判断すると考兄られる範囲を变数の色別にまと めたものを Fig. 7 亿示す。この図からわかるように白 色の領域は黒体軌跡汇沿って下側飞存在する長方形でか なりの範囲の色温度を含先。な特, 四に䄧いて変数の色 別共通の範囲をドットで示してある.

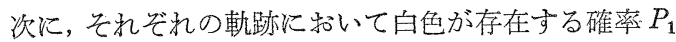
が 0.5 以上，すなわち 25 回中 13 回以上白色が存在する 軌跡上の測定点について，xy 色度図上で標準偏差を求 めると Table 2 亿示す值となる。これらの值は全体に大 きく一般にいら㚏別闒というより判断基準の安定性とい 観点から意味を有すると考光られる. 変数の色別にみ ると MacAdam の色差楕円の傾向と一致し, 变数赤, 緑, 青の順に偏差が大きくなっているが; 有意差はな い,な和， $u v$ 色度図上で標準偏差を求めた場合，観測 者によっても多少異なるが，4１5 $\times 10^{-3}$ の範团で, 頻度 の多い值は大体 $7 \times 10^{-3}$ である.

第正実験 人間の反応の形が初的にのべたよ5に正規

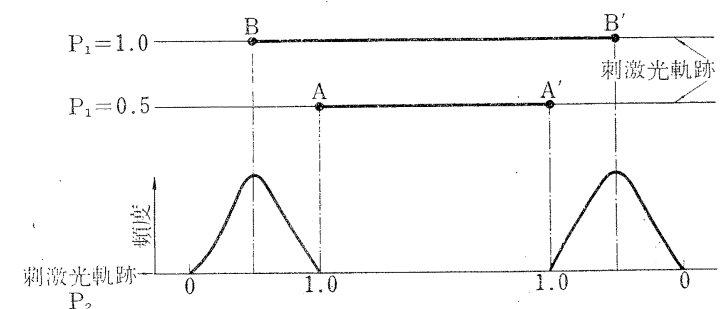

FIG.8. 確率 $P$ が 0.5 で判断される白色点
分布で，かつ，刺激連続体と反応連続体が直線的な関係 にあるという仮定に招いて, 白色が 0.5 の確率 $P$ で選択 される測定点の位置は, その刺激光軌跡上に白色が存在 する確率 $P_{1}$ とその特定の刺激光軌跡上で選択される確

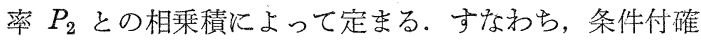
率で $P_{1}=0.5$ のときの $P$ の位置は, 特定の刺激光軌跡 上の $P_{2}=1.0$ の位置でこれを図に示すと Fig. 8 の A 怙よび $\mathrm{A}^{\prime}$ となる。实た， $P_{1}=1.0$ のときの $P$ の位置は $P_{2}=0.5$ となり Fig. 8 の B 拉よび $\mathrm{B}^{\prime}$ となる. 本実験 の場合, $P_{2}$ の值は $P_{1} \cdot P_{2}=P=0.5$ の関係から決まり これより上述の仮定にしたがって偏差率 $Z$ が次の関係式 から算出される。

$$
P_{2}=\frac{1}{\sqrt{2 \pi}} \int_{-\infty}^{Z} e^{-Z^{2 / 2}} \cdot d z
$$

ただし， $Z$ の分布は平均が 0 , 標準偏差が 1.0 の単位 正規分布である. この場合, 特定の軌跡上の $P_{2}$ の位置, すなわら, 確率 0.5 で判断される位置は平均值から標準 偏差を単位とした偏差率の長さに相当する。

ところで, 確率 0.5 で判断される白色点を求めるため に確率 $P_{1}$ が 0.5 以上の軌跡に和壮る白色点の分布（慓 準偏差）を知る必要がある，そこで，第 I 実験で $P_{1}$ が 0.5 以上の軌跡について，それらの軌跡を毎実験時に必 ず 10 回ずつ用いる実験を 10 回にわたって行なった。求 めた各測定点の $x y$ 座標を $u v$ 座標に変換し, サンプル数 100 として $u v$ 色度図上の距離で標準偏差を求めた. 次 に, 第 I 実験の結果得た白色点拉よび確率 $P_{1}$ と, 第 II 実験の結果得た標準偏差からuv 色度図上に和いて確率 0.5 で判断される白色点を求めた. さらにこれらの白色 点を $x y$ 色度座標に変換し, 観測者別に結果学示すと Fig. 9のような点となる.

ところで，輝度が汪ぼ同一で変数の色別による相遠が

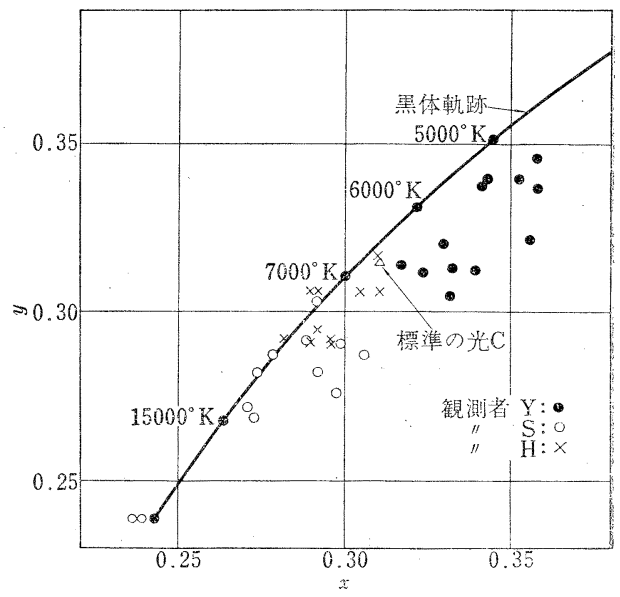

FIG.9. 確率 0.5 で判断される白色点 
少ないとすれば，白色感域は一つの平面上で形づくら れ, 白色点は白色感域の周囲上全体に点在すると考光ら れる. そして, これらの色点から白色感域を数式で近 似することが可能であるが，ここでは MacAdam の色 差棈円のように楕円で近似することを試みた.一般に, 二次曲線は次の式の左辺の（）で与兄られるが，これら の係数は最小自乗法すなわら，Qの導函数を零に拉くこ とによって求められる.

$$
\Sigma\left(x^{2}+2 B x y+C y^{2}+2 D x+2 E y+F\right)^{2}=Q
$$

得られた結果を式 $(8)$ とする.

$$
x^{2}+2 b x y+c y^{2}+2 d x+2 e y+f=0
$$

次に, この二次曲線が中心 $\left(x_{0}, y_{0}\right)$ をもつと仮定し, 次の関係式(9)を用いて式(10)に変形でさる。

$$
\begin{gathered}
x=x^{\prime}+x_{0} \\
y=y^{\prime}+y_{0} \\
x^{\prime 2}+2 b x^{\prime} y^{\prime}+c y^{\prime 2}+2 d^{\prime} x^{\prime}+2 e^{\prime} y^{\prime}+f^{\prime}=0
\end{gathered}
$$

この式が原点 $(0,0)$ に中心があるとすれば対称で, $\left(x^{\prime}, y^{\prime}\right),\left(-x^{\prime},-y^{\prime}\right)$ が恒等的に等しく $d^{\prime}=e^{\prime}=0$ であ る.したがって， $x_{0}, y_{0}$ は次の連立方程式を解くことに よって得られる.

$$
\begin{aligned}
& x_{0}+b y_{0}+d=0 \\
& b x_{0}+c y_{0}+e=0
\end{aligned}
$$

また， $f^{\prime}$ は次の式から得られる。

$$
f^{\prime}=d x_{0}+e y_{0}+f
$$

このようにして, 中心 $\left(x_{0}, y_{0}\right)$ に原点を移した二次曲 線は式(10)の $e^{\prime}=d^{\prime}=0$ の形で求められる. なた, 下記 の関係式 (13) を使って座標変換する場合に, $\tan 2 \theta=$ $\frac{2 b}{-c}$ になるように $\theta$ を選ぶと基本的な楕円曲線が得ら れる.

$$
\begin{aligned}
& x^{\prime}=X \cos \theta+Y \sin \theta \\
& y^{\prime}=X \sin \theta+Y \cos \theta
\end{aligned}
$$

このような解法にしたがって, 電子計算機 HIPAC 103

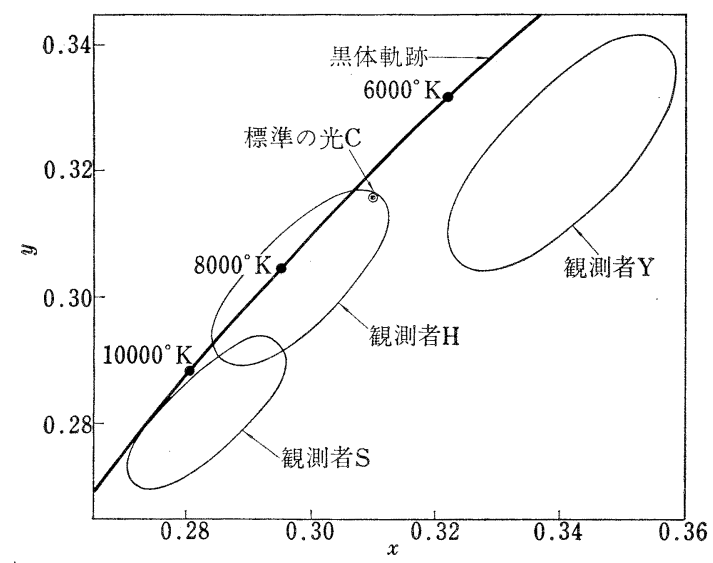

FIG. 10. 白色感域の棈円による近似
用プログラムを作成し Fig. 9 の白色点から白色感域を 求めたのが Fig. 10 である。この図から楕円の長軸はい ずれの観測者に和いても黒体軦跡に大体平行であるが, 観測者によって白色と判断する領域が異なる。すなわ ち, 観測者 3 人共有の領域はなく, 観測者 $\mathrm{Y}$ は標準の光 $\mathrm{C}$ より色温度の低い刺激光を, 観測者 $\mathrm{S}$ は観測者 $\mathrm{H}$ より 色温度の高い色光を白色と判断する。マンセル色紙で代 表される物体色については標準の光 Cを白色の中心と考 えているが，本実験の結果に执いて，標準の光Cを比較 的高い頻度で白色と判断するのは観測者Hだけである。

このように白色感域については，恐らく白色判断の基準 の不一致によるものと考光られる゙，個人差が存在する ことが推定される。な捻，白色感域を楕円で近似した場 合，そのあてはまりの良さを表わすパラメータとして焦 点までの距離の和が考えられる。すなわち，楕円周囲上 の点と焦点 $\mathrm{F}, \mathrm{F}^{\prime}$ に至る距離の和は一定で，これを $2 l$, パラメータを $P_{r}$ で表わせば次の式で求められる.

$$
P_{r}=\frac{\sum^{n}\left(\bar{P}_{i} F+\bar{P}_{i} F^{\prime}-2 l\right)}{m}
$$

ここに,

$P_{i}$ : 白色点

観測者 $\mathrm{Y}, \mathrm{H}, \mathrm{S}$ の $P_{r}$ の值はそれぞれ 0.0023，0.0015， 0.0009 であり，比較的あてはまりの良い結果を示して いる.

\section{考察}

感覚の反応に対し $x y$ 座標に打いて平均值を求める と，あたかも等間隔性を認めているようで䂑問を有す る.そこで，本実験では等間隔性を有すると考兄られる $u v$ 座標を使用して結果の処理を行なった. そして, 第 I 実験の結果得られた白色点について従来用いられてい る $x y$ 座標で処理した值と比較すると, $x y$ 色度図上で ほぼ 0.0002 の差であった. したがって，実験の目的如 何によってはすべて $x y$ 座標で処理しても大きな䛊差は 生じないと考えられる。

第 I 実験では予め定めた軌跡を毎実験時 1 度ずつ用い て行なう実験を25回行なったが，これはもしろarbitrary な判断で白色感域を求めたものでそのバラッキは当然大 きいと考觉られる。そこで，第正実験では一定の時間内 に和ける判断のバラッキがぞの程度のものか，また，判 断の基準が誤差ではなく実際に変動するものか否かを検 討するために，毎実験時 10 度ずつ用いて行なう実験を 10 回行なった.な拉, 確率 0.5 の白色点を算出する際 に標準偏差をサンプル数 100 としたのは，実験の目的か ら判断基準のバラッキも含めた方がよいと考えたためで ある. 各測定点の結果について, 測定回数を級内変動, 実験日時を級間変動とする分散分析を行なったところ， いずれの場合も有意差が認められた。すなわち，判断の 基準が実験の日時によって異なることがわかった。亦 
た，一定時間内の偏差について 10 回の標準偏差の平均 を求めたところ, 大体 $4 \sim 15 \times 10^{-3}$ の範囲で変数赤, 緑, 青の順に大きい結果を示した. 一般にはこのような条件 下の偏差を標準偏差とするが，今，標準偏差をのとし判 断の分布の形が正規分布であると仮定した場合, 0.6745 . のが確率誤差（弁別閾）となる.したがって, 確率誤差 と直線的な関係にある標準偏差の值をもって, 変数の色 別あるいは観測者別に比較すると各条件下の弁別の相異 が比較されるわけである，本実験の場合， $x y$ 座標で検 討すると青一白一黄の弁別間は赤一白一青緑の弁別間に 比べて大きくなっている．また，観測者別にみると観測 者Yのみ緑一白一紫の弁別が赤一白一青緑の弁別閾に比 ベて大きくなっている。な括, この確率誤差の平均值の 推定を示すために次の式から標準誤差 $\sigma_{M}$ を求めたとこ ろ $x y$ 座標で $2 \sim 5 \times 10^{-4}$ となった。

$$
\sigma_{M}=\frac{\sigma}{\sqrt{n-1}}
$$

ここに,

$\sigma:$ 確率誤差の標準偏差

$n$ : サンプル数

ところで，本実験の弁別閾について輝度を同一と考穴 ている点など多少問題を残すが，色差弁別間と弁別間の とら方について留意する必要があると考兄られる。す なわら，色度座標中心に考えるとある観測者にとって色 差弁別とはいい難い場合がある、たと党ば，本実験から わかるように白色感域には個人差があるわけで，特定の 色度を有する刺激光が， ある観測者には丁度白色と色味 の境界近くに存在し, 別の観測者には白色感域中心に存 在する場合，この刺激光中心に升別間を求めると前者の 場合は比較的小さく，後者の場合は大きくなることが考 えられる、したがって, 色差の并別閾を考学る場合, 刺 激光の色度中心に行ならのではなく，色の変化中心に考 えて各観測者別に，たとえば赤から白色に変わる場合の 弁別閾を求める必要があると考学られる. Table 2 参照。 次に, 本実験の観測者はいずれる色彩実験の経験を有す るので, これと比較する意味で未経験の者 1 名に対して

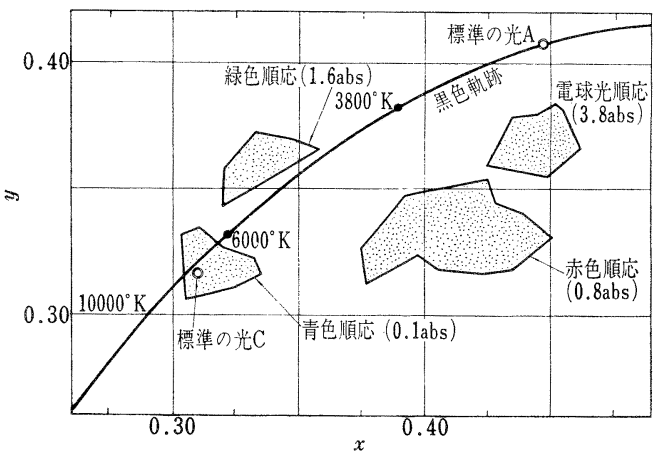

FIG. 11. 色順応下の白色感域 (( ) は順応光の輝度)
手続は異なるが同様な実験を行なった。その結果，少な くとも 1 回白色と判断する白色感域は黒体軌跡を長軸と するかなり広い楕円で色温度 $4500^{\circ} \mathrm{K} \sim 30000^{\circ} \mathrm{K}$, 短軸が $\pm 50 \mathrm{MPCD}$ の形状を呈した。

また，Fig. 1 に示す実験装置により，呈示する刺激光 の周囲を赤, 緑, 青むたは電球光で照明して実験を行な ったところ，Fig. 11 に示すように青色光で照明した以 外, 白色感域が照明光の色度方向に移動することがわか った. 青色光で照明した場合, 周囲の輝度が低く色順応 の効果が得られなかったためと考劣られる。市た，電球 光で照明した場合, 白色感域が標準の光Aの色度座標よ り下側に移動したのは視野部内面の相互反射により, 周 囲視野の色度がこの方向に変わったためとも考えられ る.な打，Fig. 11 の白色感域は各観測者が少なくとる 1 回白色と判断すると考学られる範囲である。

\section{要 約}

3 本のベンチ上にそれぞれ電動操作でその位置を連続 的に変化できる光度標準電球を点灯し，それぞれ色ガラ スフィルタを組合せて同一の拡散面を同時照射して刺激 光を呈示する装置を製作した. そして, 分光測光器, 光 電管などを用いて, 色度, 輝度などの校正を行なった。 また，刺激光の色度が $x y$ 色度図上で直線的に，かつ， 白色と判断される刺激光の輝度が大体 $20 \mathrm{abs}$ になるよ うに 3 個の電球の うち, 2 個の電球の位置を固定して刺 激光の軌跡を予め定めた.

（1）このような装置を用いて実験を行ない，色彩の 実験に経験を有する観測者 3 名についてそれぞれ確率 0.5 で判断する白色点を推定し, さらに, これらの白色 点から白色感域を棈円で近似した. その結果, 観測者 3 名共通の白色感域は存在しないが，それ毞れ黒体軌跡か らその下側に存在することがわかった．これは白色の中 心が標準の光 Cであるといら従来の通説と異なるもので ある. 本実験の結果から比較的高い頻度で標準の光 Cを 白色とみなす者は 3 名中 1 名である。

（2）一方，3 名中少なくとも 1 名が，少なくとも 1 回白色と判断する領域は黒体軌跡の下側に沿った広い領 域で，色温度でい党ば $4500^{\circ} \mathrm{K} \sim 25000^{\circ} \mathrm{K}$ に扝よぶ。

（3）色彩の実験に未経験な者 1 名について，少なく とも 1 回は白色と判断する領域を求めたところ, 極めて 広い領域を有乙黑体軌跡を長軸（色温度 $4500^{\circ} \mathrm{K}$ $\left.30000^{\circ} \mathrm{K}\right)$ とするほぼ棈円の形状を呈した。

（4）先の観測者 3 名について, 周囲を赤色光, 緑色 光, 青色光または電球光で照明した場合，一般に，照明 光の色度方向に白色感域が移動することがわかった。

（5）白色の判断を毎回 1 度づつ求めた場合のバラッ キは $x y$ 色度図上で大体 $0.007-0.02$ ，また，一定時間 内に持けるバラッキは大体 0.004-0.008 と考觉られる。 


\section{引用 文 献}

Cr. CIE. 1963 Recommendations from Commitee E-1.3.1 Vol. A, 113-114.

Helson, H., \& Michels, W.C. 1948 The effect of chromatic adaptation on achromaticity. J. opt. Soc. Amer., 38, 1025-1032.

Hurvich, L. M. , \& Jameson, D. 1951 A psychophysical study of white. I J.opt.Soc. Amer., 41, 521-527.

Hurvich, L. M., \& Jameson, D. 1951 A psychophysical study of white. II J.opt. Soc. Amer.,
41, $528-536$.

Hurvich, L. M., \& Jameson, D. 1951 A psychophysical study of white. III J.opt.Soc. Amer., 41, 787-801.

金子隆芳 1965 均等色差空間構成の諸問題 心研, 35, $306-319$.

Kelly, K.L. 1943 Color designations for lights. J. opt. Soc. Amer., 33, 627-632.

日本規格協会 1967 光源の演色性評価法 JIS Z 8726 .

- 1968. 10. 11. 受稿

\title{
WHITE SENSORY REGIONS APPROXIMATED BY ELLIPTICAL SHAPE
}

\author{
KAZUO HONJO \\ The Central Research Laboratory, Hitachi, Ltd.
}

\begin{abstract}
The experimental apparatus used of three gas-filled tungsten lamps, three glass filters and a flashed opal glass. The flashed opal glass was illuminated by three colored lights actuated by the three lamps in conjunction with the three filters. The transmitted light through this glass was the stimulus light. The distance between the surface of the flashed opal glass and each of the lamps could be varied continu. ously by means of a driving motor.

The chromaticity and the luminance of the stimulus light were calibrated by a spectrophotometer, a phototube, etc. The positions of the two of the three lamps were fixed so that the locus of the stimulus light was straight on the chromaticity diagram and the luminance in the white sensory region was about 20 abs. The observers changed the position of remaining lamp by the method of minimal
\end{abstract}

changes to determine the white points.

The results are summarized as follows.

1) The white points were determined which could be judged white with a probability of 0.5 by three observers experienced in color experiments, and the white sensory region was obtained from these white points by elliptical approximation. It was found that the white region varied in position in the different observers, but for every observer, it was located below the black body locus. This is different from a common opinion that the central point of white on the chromaticity diagram is the chromaticity coordinate of the C.I.E. standard source $\mathrm{C}$. In the experiment, the light of the C.I.E. standard source $\mathrm{C}$ was recognized frequently as white only by one of the observers.

2) The white sensory region which was judged at least as white by any one of the three observers was a rather broad zone along the downside of the black body 
locus (color temperature $4,500^{\circ} \mathrm{K}$ to 25,000 $\left.{ }^{\circ} \mathrm{K}\right)$.

3) The white sensory region which was judged at least once as white by an observer inexperienced in color experiments was very wide and presented an approximate ellipse having the normal line on the black body locus (color temperature $4,500^{\circ} \mathrm{K}$ to $30,000^{\circ} \mathrm{K}$ ).

4) When the surrounding field was illuminated by a red light or a green light or a blue light or a tungsten lamp, the white sensory region moved towards the chromaticity of the adaptation field in all the three experienced observers.

5) When the white judgement was made arbitrarily only in each experiment, the variation was 0.007 to 0.02 on the $x-y$ chromaticity diagram. When the same judgement was made ten times in each experiment for a given time, the variation for the time was 0.004 to 0.008 . 